\title{
Bioassay and alpha spectrometry in indirect monitoring of Spanish workers exposed to enriched uranium
}

\author{
Inmaculada Sierra, Carolina Hernández, Paula Albendea, and Maria Antonia López \\ CIEMAT Bioelimination Laboratory, Internal Dosimetry, Madrid, Spain
}

[Received in November 2018; Similarity Check in December 2018; Accepted in September 2019]

\begin{abstract}
Workers at risk of exposure to uranium compounds should be monitored and their internal exposure quantified in terms of committed effective dose $\mathrm{E}(50)$ in $\mathrm{mSv}$. In vitro bioassay methods can quantify uranium in urine and faeces at low activity levels. Alpha spectrometry (AS) is the most common method used for monitoring alpha-emitting radionuclides in internal dosimetry services. It provides isotopic information and low minimum detectable activity (MDA) values $(\leq 0.50 \mathrm{mBq}$ per sample). This study reports the results of a five-year monitoring of workers exposed to uranium at a Spanish Juzbado facility, which produces nuclear fuel elements enriched with up to $5 \%$ of ${ }^{235} \mathrm{U}$. Monitoring included about 100 workers per year, most of whom had worked at the facility for more than 10 years before the individual monitoring programme was established. We analysed nearly 550 samples of more than 200 workers over five years. The obtained results indicate that workers were adequately protected from uranium exposure through inhalation and had an acceptably low chronic intake at the facility.
\end{abstract}

KEY WORDS: indirect bioassay; internal dosimetry; urine samples; uranium isotopes

The Juzbado facility of ENUSA Industrias Avanzadas S.A. (ENUSA) located in Salamanca (Spain) manufactures nuclear fuel elements for Spanish nuclear power plants. Its annual production capacity is 500 tof up to $5 \%{ }^{235} \mathrm{U}$-enriched uranium (1). The manufacturing process puts more than 200 workers at risk of internal exposure, which is why they need to be monitored for internal exposure. Since 2014, CIEMAT has been assessing internal dosimetry of permanent staff of the facility (around 100 workers per year) in terms of committed effective dose $\mathrm{E}(50)$ in $\mathrm{mSv}$. As in vivo methods are not always adequate for quantifying exposure to alpha emitters because their detection limits are too high (2), in vitro bioassay methods are preferred, as they quantify uranium in urine at low activity levels $(3,4)$. This is particularly relevant for radionuclides incorporated into the body as insoluble compounds through inhalation, because in this case the urinary excretion of uranium isotopes is low and slow (5).

The CIEMAT Bioelimination Laboratory uses three indirect methods of quantifying uranium: kinetic phosphorescence analysis (KPA), inductively coupled plasma-sector field mass spectrometry (ICP-SF-MS), and alpha spectrometry (AS). KPA or ICP-MS are employed for screening workers at risk of internal contamination by natural uranium. If the results obtained with these methods are above detection limit $(0.10 \mu \mathrm{g} / \mathrm{L}$ for KPA and $0.004 \mathrm{mBq} / \mathrm{L}\left({ }^{238} \mathrm{U}\right)$ for ICP-MS), an isotopic analysis with

Corresponding author: Inmaculada Sierra, CIEMAT, Bioelimination Laboratory, Av. Complutense 40, 28040 Madrid, Spain

E-mail:inma.sierra@ciemat.es
AS is the next step. It is the reference and most common method used for monitoring alpha-emitting radionuclides in internal dosimetry services, as it provides isotope information and has a low minimum detectable activity (MDA) $\leq 0.50 \mathrm{mBq}$ per sample. However, it takes tedious chemical processing to isolate actinides from inactive substances and separate them from other radioisotopes which may interfere with AS measurement. It also takes long counting times (3-5 days) (3-7).

The aim of this study was to establish potential internal exposure of workers at the Juzbado facility to enriched uranium compounds by monitoring about 100 workers per year over five years (2014-2018). Most of these workers had been working at the facility for more than 10 years before the individual monitoring program was established. We applied a new method developed for the separation and analysis of uranium isotopes $\left({ }^{238} \mathrm{U},{ }^{236} \mathrm{U},{ }^{235} \mathrm{U}\right.$, and $\left.{ }^{234} \mathrm{U}\right)$ in urine samples using ion exchange chromatography and alpha spectrometry. It is an adaptation of an older procedure used at our laboratory (8), and its main novelty is that it can be applied for chronic inhalation scenarios. Earlier measurement methods (such as in vivo whole body counter and kinetic phosphorescence analysis in urine) were less sensitive and used only for accidental exposures or when activity was above the detection limit, in which case they were followed up by AS to confirm contamination. Since 2014, CIEMAT has established an improved radiochemical procedure for individual monitoring of Spanish workers exposed to enriched uranium for 10-30 years as part of routine internal exposure monitoring programme (9). The 
accuracy and reliability of this analytical procedure have been tested and validated at international intercomparison exercises. CIEMAT Bioelimination Laboratory also has the ISO/IEC 17025 accreditation since $2012(10,11)$.

This report presents the activity results ( $\mathrm{mBq} /$ day) of a five-year monitoring of urine samples taken from the Juzbado workers, which reflect their chronic intake (internal doses) through inhalation.

\section{METHODS AND VALIDATION}

Chronically inhaled internal doses are assessed following the International Commission on Radiological Protection (ICRP) recommendations and biokinetic models $(12,13)$. Routine monitoring of workers exposed to enriched uranium (3-5\%) assumed only inhalation intake and chronic exposure. The intake scenario assumed exposure to uranium oxides with type $\mathrm{S}$ of solubility and a default particle size of $5 \mu \mathrm{m}$ of activity median aerodynamic diameter (AMAD) (9). For that purpose 24-hour urine samples were required, initially at annual frequency. New employees gave a urine sample before exposure began for background subtraction.

Samples were collected and creatinine content was determined according to the method described by Young (14), based on the formation of a coloured complex with a basic picrate solution. Sample volume was corrected assuming an average creatinine excretion rate of $1.7 \mathrm{~g} /$ day for men and $1.0 \mathrm{~g} /$ day for women (15) to normalise radionuclide amount measured in the sample to the equivalent of a true 24-hour collection.

\section{Analytical procedures}

All chemicals used were of analytical grade quality and solutions were prepared with deionised water. Anion exchange resin AG1-X8 (100-200 dry mesh, chloride form) was purchased from Bio-Rad Laboratories (Irvine, CA, USA). Radionuclide reference solution used as tracer $\left({ }^{232} \mathrm{U}\right)$ was metrologically traceable to the Ionizing Radiation Metrology Laboratory (LMRI) of CIEMAT.

Figure 1 shows a flow chart of the analytical procedure used to determine uranium isotopes in urine, which consists of three main preparation steps (pre-concentration step, radiochemical separation, and electrodeposition) prior to AS.

\section{Pre-concentration step}

The whole sample was transferred into a glass beaker, acidified with concentrated $\mathrm{HNO}_{3}(65 \%)$, and $1 \mathrm{~mL}$ of concentrated phosphoric acid ( $85 \%$ ) was added to initiate the process. Isotopic tracer $\left({ }^{232} \mathrm{U}\right)$ was added to quantify recovery of the analytical procedure. Sample and tracer were equilibrated by heating and magnetic stirring in a water bath at $80{ }^{\circ} \mathrm{C}$ for at least $30 \mathrm{~min}$. Uranium isotopes were then co-precipitated with calcium phosphate in ammonia with continuous stirring for $1 \mathrm{~h}$. The precipitate was left to settle overnight and was then separated by decanting and centrifugation. The supernatant was discarded and the precipitate centrifuged, washed with $2 \mathrm{~mol} / \mathrm{L}$ of $\mathrm{HNO}_{3}$ and finally evaporated to dryness. The residue was then wet ashed up to five times with 3-5 mL of concentrated $\mathrm{HNO}_{3}$ at $300{ }^{\circ} \mathrm{C}$. Finally, the obtained residue was dissolved in $50 \mathrm{~mL}$ of $\mathrm{HCl}(10 \mathrm{~mol} / \mathrm{L})$.

\section{Radiochemical separation}

Uranium was isolated by anion exchange chromatography using AG1-X8 resin. About 8-10 g of resin (suspended in $\mathrm{H}_{2} \mathrm{O}$ ) was transferred into a glass column and rinsed with $2 \times 30 \mathrm{~mL}$ of $10 \mathrm{~mol} / \mathrm{L} \mathrm{HCl}$. The sample solution was then loaded in the column, and the resin washed with $4 \times 25 \mathrm{~mL}$ of $10 \mathrm{~mol} / \mathrm{L} \mathrm{HCl}$. Uranium isotopes were then eluted with $4 \times 20 \mathrm{~mL}$ of $0.5 \mathrm{~mol} / \mathrm{L} \mathrm{HCl}$.

\section{Electrodeposition}

The uranium fraction was evaporated to dryness and prepared for alpha particle counting by electrodeposition following the procedure described by Hallstadius (16).

\section{Alpha spectrometry}

Alpha spectra were measured with an integrated Canberra Alpha Analyst instrument (Model 7200) (Meriden, CT, USA) equipped with passivated implanted planar

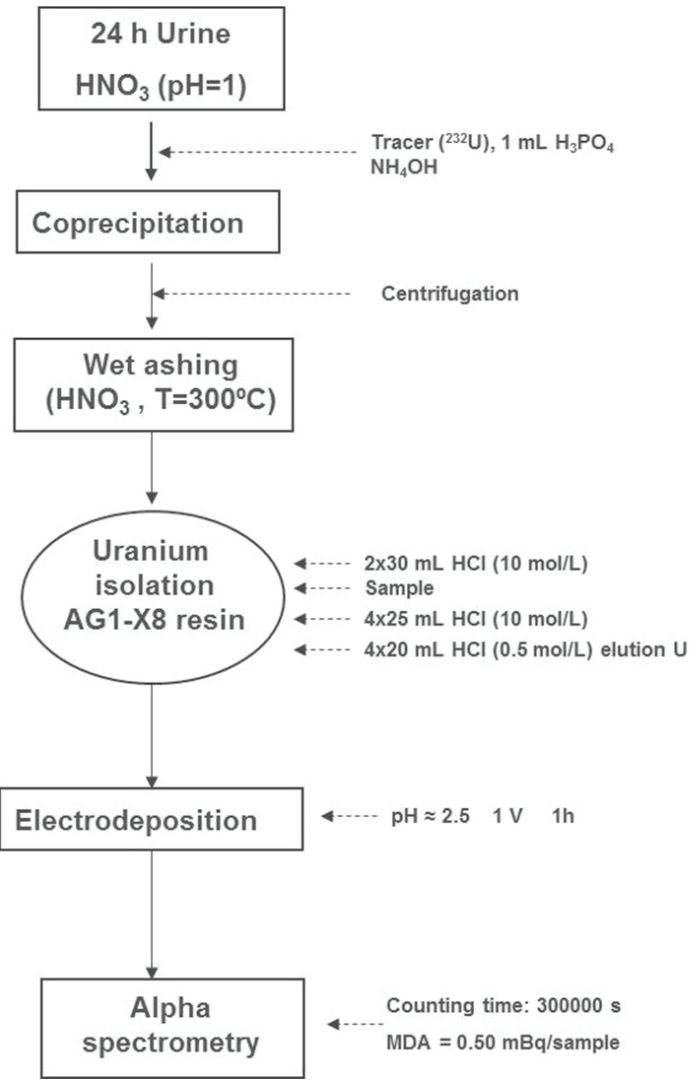

Figure 1 Flow chart of the analytical procedure for the measurement of uranium isotopes in 24-hour urine samples 
silicon detectors with a $450 \mathrm{~mm}^{2}$ active area and full width at half-maximum (FWHM) alpha resolution of $18 \mathrm{KeV}$ at $5.48 \mathrm{MeV}$.

Figure 2 shows a typical spectrum with enriched uranium isotopes (the ${ }^{232} \mathrm{U}$ peak is due to the tracer added). The typical energy resolution of a monoenergetic (or nearly monoenergetic) peak in the alpha spectrum in urine samples ranged between 20 to $30 \mathrm{KeV}$.

\section{Internal dose assessment}

The committed effective dose $\mathrm{E}(50)$ was calculated using Integrated Modules for Bioassay (IMBA) internal dosimetry software (17) and applying IDEAS Guidelines (General guidelines for the estimation of committed effective dose from incorporation monitoring data) (18) together with the methodology described in ISO 27048 (19) and ISO 16638-1 (5) standards for the estimation of uncertainty and the calculation of intake, including the verification of the "goodness of fit" to confirm that experimental data follow the prediction of the excretion model for the intake scenarios.

\section{Quality assurance of the analytical method}

The complete method was validated and uncertainty estimated according to accreditation requirements (20). Furthermore, the whole procedure and its results underwent quality assurance through participation in intercomparison exercises. Every year, the CIEMAT laboratory participates in different intercomparison exercises organised by the German Federal Office for Radiation Protection BfS (Bundesamt für Strahlenschutz) (21) and the French association PROCORAD (Association pour la Promotion du Contrôle de Qualité des Analyses de Biologie Médicale en Radiotoxicologie) (22).

Table 1 shows the results validated by the BfS exercise "BfS-Rv-2015-U-nat" in 2015 and PROCORAD intercomparison exercise "Uranium in Urine Exercise" in 2018. Bias and Z-score were within the confidence interval defined by ISO $28218(23)[-25 \%,+50 \%$ and $\leq 2$, respectively].

\section{RESULTS AND DISCUSSION}

From 2014 to 2018 , nearly 550 urine samples (between 77 and 133 a year) from more than 200 workers (about 100 a year) were analysed with this radiochemical method. The obtained tracer recoveries in Table 2 show the reliability and robustness of the whole procedure. Thanks to these average recoveries, counting time of $300.000 \mathrm{~s}$, counting efficiency of 26-31\%, and typical background range of 0-4 counts, MDA was lowered to $0.05-0.19 \mathrm{mBq}$ per sample. The need for lowering MDA is the consequence of extremely low daily urinary excretion rates for uranium radionuclides.

Activity results showed great variability, from values below MDA to activity rates of $18.89 \mathrm{mBq}$ /day. However, most were below $5 \mathrm{mBq}$ /day (Figure 3). The most significant average activity of ${ }^{234} \mathrm{U}$ of around $2-3 \mathrm{mBq} /$ day remained stable throughout the five years of monitoring. Only $5.6-17.7 \%$ of the analysed samples had activity higher than $5 \mathrm{mBq}$ /day. More precisely, it was stable at about $7 \mathrm{mBq} /$ day. For this reason, routine monitoring programme

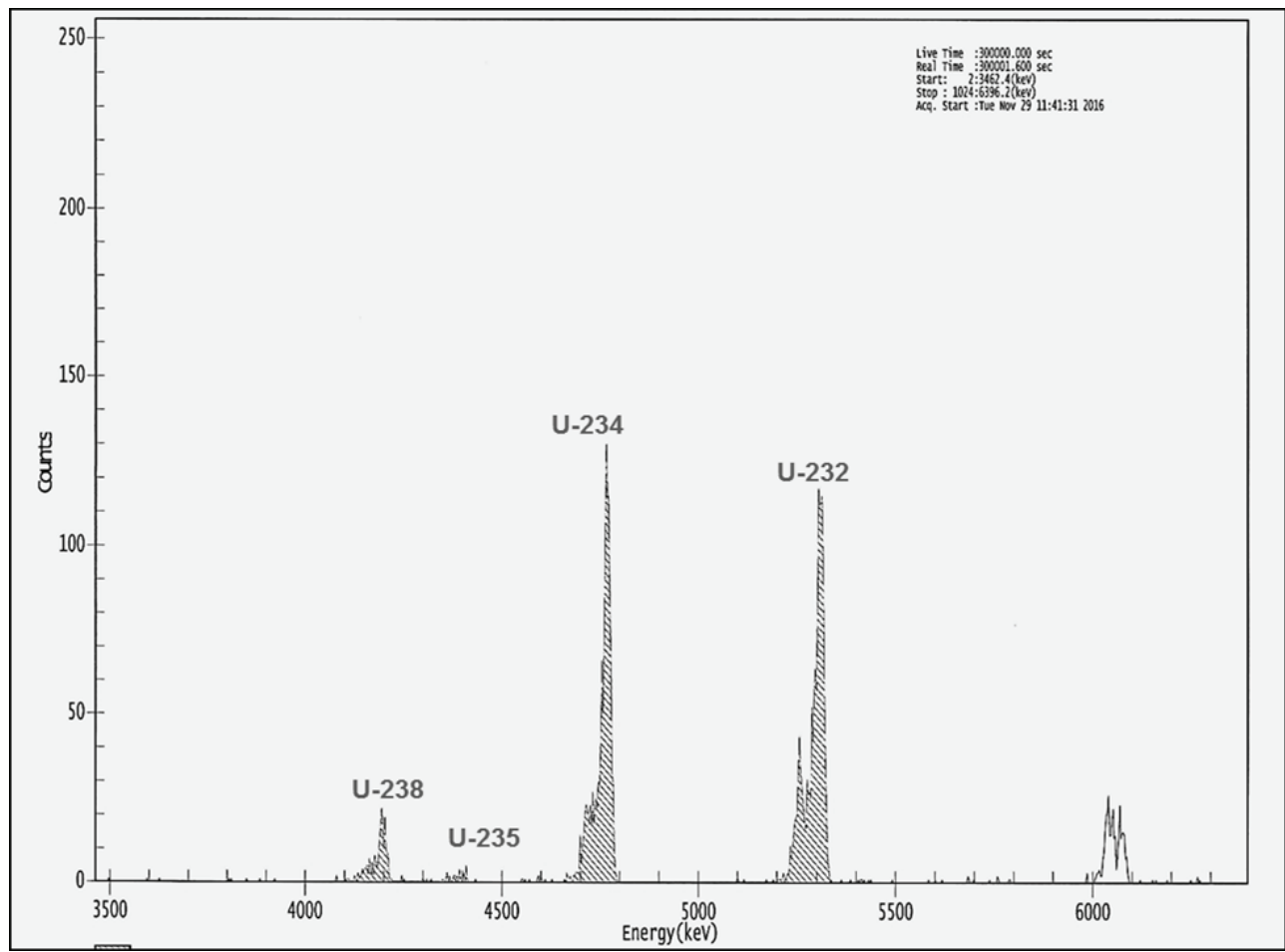

Figure 2 Typical alpha spectra for enriched uranium isotopes in a 24-hour urine sample 
Table 1 Uranium isotope target values and activity concentrations measured in the $2015 \mathrm{Bfs}$ sample and in the 2018 PROCORAD samples

\begin{tabular}{|c|c|c|c|c|c|}
\hline \multicolumn{2}{|c|}{ BfS exercise (2015) } & \multicolumn{4}{|c|}{$\mathrm{mBq} / \mathrm{L}$} \\
\hline Sample & Nuclide & Target value & Measured value & Bias (\%) & Z-score \\
\hline A & ${ }^{234} \mathrm{U}$ & $49.9 \pm 1.57$ & $45.5 \pm 1.66$ & -9 & 0.442 \\
\hline A & ${ }^{235} \mathrm{U}$ & $2.34 \pm 0.16$ & $2.33 \pm 0.22$ & 0 & $<0.10$ \\
\hline A & ${ }^{238} \mathrm{U}$ & $50.9 \pm 1.35$ & $46.1 \pm 1.49$ & -10 & 0.478 \\
\hline \multicolumn{3}{|c|}{ PROCORAD exercise (2018) } & \multicolumn{2}{|c|}{$\mathrm{mBq} / \mathrm{sample}$} & \\
\hline Sample & Nuclide & Target value & Measured value & Bias (\%) & Z-score \\
\hline \multirow[t]{3}{*}{ A } & ${ }^{234} \mathrm{U}$ & $143.0 \pm 11.3$ & $140.0 \pm 14.0$ & -2 & -0.2 \\
\hline & ${ }^{235} \mathrm{U}$ & $6.87 \pm 0.54$ & $6.49 \pm 0.78$ & -6 & -0.3 \\
\hline & ${ }^{238} \mathrm{U}$ & $142.0 \pm 9.4$ & $140.0 \pm 15.4$ & -1 & -0.2 \\
\hline \multirow[t]{3}{*}{$\mathrm{B}$} & ${ }^{234} \mathrm{U}$ & $37.1 \pm 3.74$ & $34.0 \pm 4.42$ & -8 & -0.8 \\
\hline & ${ }^{235} \mathrm{U}$ & $1.81 \pm 0.18$ & $1.49 \pm 0.22$ & -18 & -1.0 \\
\hline & ${ }^{238} \mathrm{U}$ & $36.7 \pm 3.34$ & $34.2 \pm 4.44$ & -7 & -0.9 \\
\hline
\end{tabular}

Table 2 Uranium activity $\left({ }^{234} \mathrm{U}\right)$ findings in the urine samples of the Juzbado workers

\begin{tabular}{|c|c|c|c|c|}
\hline \multirow{2}{*}{ Year } & \multirow{2}{*}{$\begin{array}{c}\text { Average } \\
\text { recovery (\%) }\end{array}$} & \multirow{2}{*}{ Total samples } & Average activity (mBq/day) & \multirow{2}{*}{ Average activity $>5 \mathrm{mBq} /$ day } \\
\hline & & & >MDA (0.50 mBq/sample) & \\
\hline 2014 & 78 & 77 & $3.25 \pm 0.47(\mathrm{n}=76)$ & $6.97 \pm 0.79(n=14)$ \\
\hline 2015 & 69 & 98 & $2.56 \pm 0.48(\mathrm{n}=90)$ & $7.86 \pm 0.98(n=11)$ \\
\hline 2016 & 81 & 126 & $2.47 \pm 0.38(\mathrm{n}=110)$ & $8.37 \pm 0.91(\mathrm{n}=15)$ \\
\hline 2017 & 83 & 133 & $2.02 \pm 0.34(\mathrm{n}=124)$ & $7.41 \pm 0.86(n=8)$ \\
\hline 2018 & 81 & 114 & $1.98 \pm 0.31(\mathrm{n}=105)$ & $7.22 \pm 0.78(\mathrm{n}=7)$ \\
\hline
\end{tabular}

frequency for the most exposed workers (receiving $5 \mathrm{mSv}$ / year or more) was doubled from annual to biannual.

Furthermore, these monitoring findings suggest that the workers at the Juzbado facility were effectively protected from uranium exposure through inhalation and had an acceptably low chronic intake.

Based on the ${ }^{234} \mathrm{U}$ alpha spectrometry results with MDA of $0.5 \mathrm{mBq} /$ day) and the isotopic composition of enriched uranium of around $4 \%$, the committed effective dose $\mathrm{E}(50)$ for a worker who exposed to chronic inhalation for 10 years when the first 24-hour urine sample is collected was calculated to be around $0.3 \mathrm{mSv} /$ year.

\section{CONCLUSIONS}

The analytical methodology developed by CIEMAT for in vitro bioassay of enriched uranium in urine is adequate to describe chronic inhalation exposure (routine monitoring) and accidental acute exposure. The obtained results prompted us to double the frequency of routine monitoring to biannual for samples of the most exposed workers at the facility. However, for most of the workers the daily activity rate of uranium isotopes in urine samples over five years confirmed low level chronic intakes and verify a correct protection of workers.

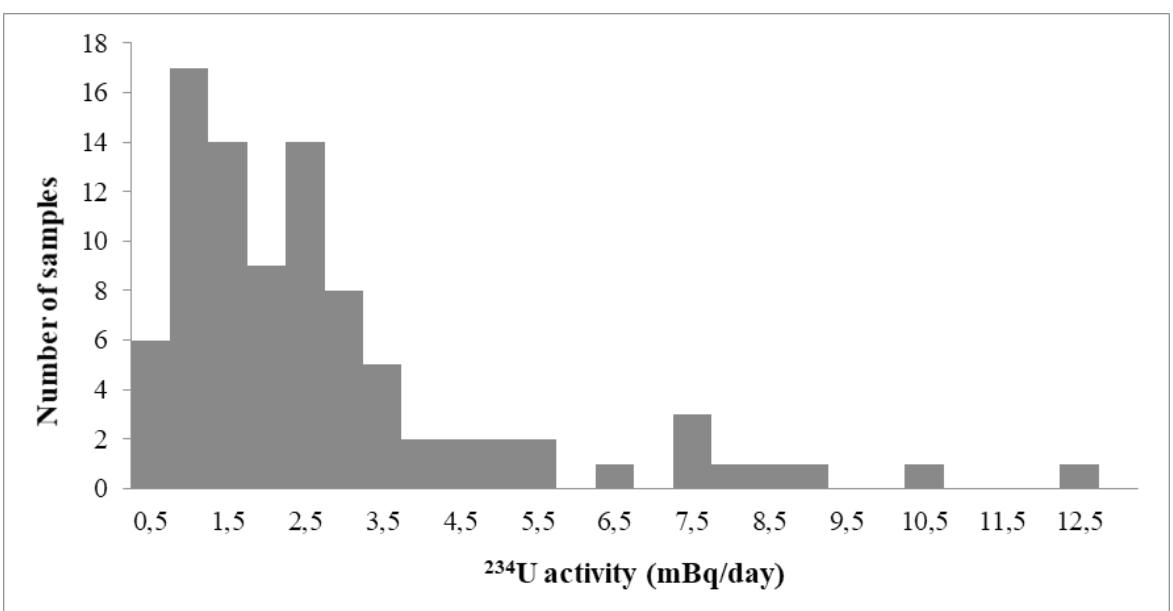

Figure 3 Distribution of ${ }^{234} \mathrm{U}$ activity (mBq/day) in 2015 


\section{REFERENCES}

1. Empresa Nacional del Uranio, SA (ENUSA) [displayed 25 July 2019]. Available at: http://www.enusa.es/en/areas-denegocio/nuclear/fabricacion/

2. ISO 11929-1:2010. Determination of the characteristic limits (decision threshold, detection limit and limits of the confidence interval) for measurements of ionizing radiation. Fundamentals and application. Geneva: International Organization for Standardization; 2010.

3. International Atomic Energy Agency (IAEA). Indirect Methods for Measuring Radionuclides in the Human Body. Safety Report Series 18. Vienna; IAEA; 2000.

4. Los Alamos National Laboratory. Manual of radiobioassay chemistry analytical techniques. LA-10300-M. Health and Environmental Chemistry, HSE-9. Los Alamos, New Mexico; Los Alamos National Laboratory; 1987.

5. ISO 16638-1:2015. Radiological protection - Monitoring and internal dosimetry for specific materials. Part 1: Inhalation of uranium compounds. Geneva: International Organization for Standardization; 2015.

6. European Commission. Technical Recommendations for Monitoring Individuals for Occupational Intakes of Radionuclides. Radiation Protection $N^{\circ} 188$. Luxembourg: Publications Office of the European Union; 2018.

7. Robredo LM, Navarro T, Sierra I. Indirect monitoring of internal exposure in the decommissioning of a nuclear power plant in Spain. Appl Radiat Isot 2000;53:345-50. doi: 10.1016/S0969-8043(00)00151-2

8. Robredo LM, Serrano J, Sierra I, Navarro T. Técnicas de medida de uranio en muestras de orina. Aplicación en dosimetría interna de uranio natural y empobrecido [Uranium measurement techniques in urine samples. Application in internal dosimetry of natural and depleted uranium; in Spanish]. In: CIEMAT. Participación del CIEMAT en la 27 Reunión Anual de la Sociedad Nuclear Española [Participation of CIEMAT in 27th annual meeting of the Spanish Nuclear Society; in Spanish] 2001; P1-23. ISBN: 84-7834-415-2.

9. López MA, Sierra S, Sierra I, Hernández C, Pérez A. Dose Assessment of workers long term exposed to chronic intakes of enriched uranium. In: The $12^{\text {th }}$ international conference on the Health Effects of Incorporated Radionuclides HEIR2018; 8-11 October 2018. Fontenay-aux-Roses, France [displayed 25 July 2019]. Available at https://www.bioconferences.org/articles/bioconf/pdf/2019/03/bioconf heir2018 03006

10. Lopez MA, Martin R, Hernandez C, Navarro JF, Navarro T, Perez B, Sierra I. The challenge of CIEMAT Internal Dosimetry Service for accreditation according to ISO/IEC 17025 standard, for in vivo and in vitro monitoring and dose assessment of internal exposures. Radiat Prot Dosimetry 2016;170:31-4. doi: 10.1093/rpd/ncv387

11. ISO/IEC 17025:2017. General requirements for the competence of testing and calibration laboratories. Geneva: International Organization for Standardization; 2017.

12. International Commission on Radiological Protection (ICRP). Individual Monitoring for Internal Exposure of Workers (preface and glossary missing). ICRP Publication 78. Oxford: Pergamon Press; 1997.

13. International Commission on Radiological Protection (ICRP). Compendium of Dose Coefficients based on ICRP Publication 60. ICRP Publication 119. Oxford: Pergamon Press; 2012

14. Young DS, Pestaner LC, Gibberman V. Effect of drugs on clinical laboratory tests. Clin Chem 1975;21:1D-432D. PMID: 1091375.

15. International Commission on Radiological Protection (ICRP). Basic Anatomical and Physiological Data for Use in Radiological Protection: Reference Values. ICRP Publication 89. Oxford: Pergamon Press; 2002.

16. Hallstadius L. A method for the electrodeposition of actinides. Nucl Instr Meth Phys Res 1984;223:266-7. doi: 10.1016/01675087(84)90659-8

17. Birchall A, Puncher M, Marsh JW, Davis K, Bailey MR, Jarvis NS, Peach AD, Dorrian M-D, James AC. IMBA Professional Plus: a flexible approach to internal dosimetry. Radiat Prot Dosimetry 2007;125:194-7. doi: 10.1093/rpd/ ncl171

18. Castellani CM, Marsh JW, Hurtgen C, Blanchardon E, Berard P, Giussani A, Lopez MA. EURADOS-IDEAS Guidelines (Version 2) for the Estimation of Committed Doses from Incorporation Monitoring Data. Radiat Prot Dosimetry 2016;170:17-20. doi: 10.1093/rpd/ncv457

19. ISO 27048:2011. Radiological protection - Dose assessment for the monitoring of workers for internal radiation exposure. Geneva: International Organization for Standardization; 2011.

20. Hernández C, Sierra I. Retrospective method validation and uncertainty estimation for actinides determination in excreta by alpha spectrometry. Radiat Prot Dosim 2016;170:39-44. doi: $10.1093 / \mathrm{rpd} / \mathrm{ncv} 418$

21. The Federal Office for Radiation Protection (BfS). Responsibility for People and the Environment [displayed 25 July 2019). Available at http://www.bfs.de

22. PROCORAD organises radiotoxicology intercomparisons in order to evaluate the quality of medical analysis results and to promote good laboratory practice [displayed 25 July 2019). Available at http://www.procorad.org

23. ISO 28218:2010. Radiological protection - Performance criteria for radiobioassay. Geneva: International Organization for Standardization; 2010 


\section{Primjena bioeseja i alfa-spektrometrije za neizravno praćenje španjolskih radnika izloženih obogaćenom uraniju}

Radnici koji su izloženi riziku od izloženosti spojevima s uranijem trebaju se pratiti i njihova unutrašnja izloženost mjeriti pomoću očekivane efektivne doze $\mathrm{E}(50)$ izražene u mSv. Uranij se može kvantificirati u mokraći čak i pri vrlo niskim razinama aktivnosti pomoću bioesejnih metoda in vitro. Najčešća metoda koja se rabi u internoj dozimetriji za praćenje/ nadziranje razina radionuklida koji emitiraju alfa-čestice jest alfa-spektrometrija. Njome se identificiraju izotopi i može otkriti nisku minimalnu aktivnost (engl. minimum detectable activity, MDA) $(\leq 0.50 \mathrm{mBq}$ po uzorku). Ovdje donosimo rezultate petogodišnjega praćenja radnika izloženih uraniju u španjolskoj tvornici sastojaka za nuklearno gorivo Juzbado, u kojoj se sastojci obogaćuju izotopom ${ }^{235} \mathrm{U}$ do udjela od $5 \%$. Pratilo se oko 100 radnika na godinu, a većina njih je radila u tvornici više od deset godina prije nego što je uveden program praćenja. Ukupno je u pet godina analizirano gotovo 550 uzoraka mokraće oko 200 radnika. Dobiveni rezultati upućuju na to da su radnici dobro zaštićeni od izloženosti uraniju udisanjem te da je kronični unos uranija u tvornici na prihvatljivo niskoj razini.

KLJUČNE RIJEČI: interna dozimetrija; izotopi uranija; neizravni bioesej; uzorci mokraće 